\title{
The contribution of fungal spores and bacteria to regional and global aerosol number and ice nucleation immersion freezing rates
}

\author{
D. V. Spracklen ${ }^{1}$ and C. L. Heald ${ }^{2}$ \\ ${ }^{1}$ School of Earth and Environment, University of Leeds, Leeds, UK \\ ${ }^{2}$ Department of Civil and Environmental Engineering, Massachusetts Institute of Technology, Cambridge, MA, USA \\ Correspondence to: D. V. Spracklen (dominick@env.leeds.ac.uk)
}

Received: 1 November 2013 - Published in Atmos. Chem. Phys. Discuss.: 10 December 2013

Revised: 1 May 2014 - Accepted: 27 July 2014 - Published: 2 September 2014

\begin{abstract}
Primary biological aerosol particles (PBAPs) may play an important role in aerosol-climate interactions, in particular by affecting ice formation in mixed phase clouds. However, the role of PBAPs is poorly understood because the sources and distribution of PBAPs in the atmosphere are not well quantified. Here we include emissions of fungal spores and bacteria in a global aerosol microphysics model and explore their contribution to concentrations of supermicron particle number, cloud condensation nuclei $(\mathrm{CCN})$ and immersion freezing rates. Simulated surface annual mean concentrations of fungal spores are $\sim 2.5 \times 10^{4} \mathrm{~m}^{-3}$ over continental midlatitudes and $1 \times 10^{5} \mathrm{~m}^{-3}$ over tropical forests. Simulated surface concentrations of bacteria are $2.5 \times 10^{4} \mathrm{~m}^{-3}$ over most continental regions and $5 \times 10^{4} \mathrm{~m}^{-3}$ over grasslands of central Asia and North America. These simulated surface number concentrations of fungal spores and bacteria are broadly in agreement with the limited available observations. We find that fungal spores and bacteria contribute 8 and $5 \%$ respectively to simulated continental surface mean supermicron number concentrations, but have very limited impact on $\mathrm{CCN}$ concentrations, altering regional concentrations by less than $1 \%$. In agreement with previous global modelling studies, we find that fungal spores and bacteria contribute very little $\left(3 \times 10^{-3} \%\right.$, even when we assume upper limits for ice nucleation activity) to global average immersion freezing ice nucleation rates, which are dominated by soot and dust. However, at lower altitudes (400 to $600 \mathrm{hPa}$ ), where warmer temperatures mean that soot and dust may not nucleate ice, we find that PBAP controls the immersion freezing ice nucleation rate. This demonstrates that PBAPs can be of regional importance for IN formation, in agreement with case study observations.
\end{abstract}

\section{Introduction}

Primary biological aerosol particles (PBAPs) include a wide range of biological particles emitted directly from the biosphere including bacteria, viruses, fungal spores, pollen and leaf debris. It has been suggested that PBAPs can make a large contribution to atmospheric aerosol (Jaenicke, 2005), influencing climate through scattering and absorbing radiation (the aerosol direct effect) and by altering the properties of clouds (the aerosol indirect effect). However, the impact of PBAPs on climate is poorly constrained. Here we quantify the contribution of fungal spores and bacteria to global and regional aerosol number, cloud condensation nuclei $(\mathrm{CCN})$ and immersion freezing rates.

The number of PBAPs emitted into the atmosphere is thought to be substantial with estimates as large as $1000 \mathrm{Tg} \mathrm{a}^{-1}$ (Jaenicke, 2005). Previous estimates of the global emission of fungal spores vary from 8 to $186 \mathrm{Tg} \mathrm{a}^{-1}$ (Elbert et al., 2007; Heald and Spracklen, 2009; Jacobson and Streets, 2009; Hoose et al., 2010b; Sesartic and Dallafior, 2011; Després et al., 2012). The global emissions of bacteria are even more uncertain, spanning nearly 2 orders of magnitude from 0.4 to $28.1 \mathrm{Tg} \mathrm{a}^{-1}$ (Burrows et al., 2009b; Hoose et al, 2010b; Jacobson and Streets, 2009; Després et al., 2012).

The majority of PBAPs are thought to be emitted at supermicron sizes (dry diameter $>1 \mu \mathrm{m}$ ), with bacteria having diameter of about $1 \mu \mathrm{m}$, fungal spores $2-10 \mu \mathrm{m}$ and pollen $30 \mu \mathrm{m}$ (Després et al., 2012). As such, PBAPs may constitute an important fraction of the number concentration of supermicron particles, especially when other supermicron aerosol (e.g. dust and sea spray) are absent (Després et al., 2012). Over the Amazon rainforest, PBAP contributes up to $80 \%$ 
(Pöschl et al., 2010) of total supermicron number concentrations. Huffman et al. (2012) reported that fluorescent biological aerosol particles (FBAPs) contribute $24 \%$ of supermicron number concentrations over the Amazon. Observations over Europe and central Asia show that PBAPs can make up $20-30 \%$ of the number concentration of particles with diameter $>0.2 \mu \mathrm{m}$ (Matthias-Maser and Jaenicke, 1995; MatthiasMaser et al., 2000), whilst other studies have found a smaller (4\%) contribution of FBAPs to supermicron number over Europe (Huffman et al., 2010). PBAPs can also make substantial contributions to supermicron particle number in the free and upper troposphere. DeLeon-Rodriguez et al. (2013) reported that bacteria can represent $20 \%$ of total particles in the $0.25-1 \mu \mathrm{m}$ diameter range at $\sim 10 \mathrm{~km}$ over the Atlantic Ocean.

PBAPs are typically considered to be efficient CCN (Bauer et al., 2003; Després et al., 2012). The low PBAP number concentrations are likely to limit the contribution of PBAPs to total CCN concentrations in most parts of the atmosphere. However, PBAPs may have a role as giant $(>2 \mu \mathrm{m}) \mathrm{CCN}$, forming cloud droplets at low supersaturations (Möhler et al., 2007; Després et al., 2012).

PBAPs may also act as ice nuclei (IN) (Möhler et al., 2007; Després et al., 2012; Murray et al., 2012). Detailed aerosolcloud models have shown that bacteria can alter the properties of clouds if present in sufficiently high number concentrations (Phillips et al., 2009). Recent atmospheric measurements have observed the presence of PBAPs in precipitation (Christner et al., 2008) and shown that IN over both the continental US (Pratt et al., 2009) and the Amazon (Prenni et al., 2009) are composed of biological particles. Prenni et al. (2009) measured IN $(<2 \mu \mathrm{m}$ diameter $)$ with a continuous flow diffusion chamber and demonstrated that carbonaceous material, dominated by biological particles, makes up $16-76 \%$ of IN in the Amazon basin during the wet season. Pratt et al. (2009) found that biological particles comprised $\sim 33 \%$ of ice-crystal residues $(<1.2 \mu \mathrm{m}$ diameter $)$ measured at $8 \mathrm{~km}$ altitude over the continental United States. Observed correlations between PBAP and IN concentrations during rain events over the continental United States further suggest an important role for PBAPs in the hydrological cycle (Huffman et al., 2013; Prenni et al., 2013). In contrast, recent modelling studies have found that PBAPs make little contribution to global ice nucleation (Hoose et al., 2010a, b; Sesartic et al., 2013). For example, Hoose et al. (2010b) simulated that PBAPs contribute less than $0.6 \%$ to the global average ice nucleation rate. However, these previous global studies have not quantified the regional contribution of PBAPs to ice nucleation which could be higher in areas of biological activity (e.g. over tropical forests) and in warm air masses (e.g. above $\sim-15^{\circ} \mathrm{C}$ ). Here we use a global aerosol microphysics model to quantify the contribution of fungal spores and bacteria to regional and global aerosol and ice nucleation.

\section{Methods}

\subsection{Model description}

We used the modal version of the Global Model of Aerosol Processes (GLOMAP-mode) (Mann et al., 2010) which is an extension to the TOMCAT global 3-D chemical transport model (Chipperfield, 2006). The model is forced by analyses from the European Centre for Medium Range Weather Forecasts (ECMWF), updated every $6 \mathrm{~h}$ and linearly interpolated onto the model time step. We ran the model for the year 2000 (after 3 months of model spin-up) at a horizontal resolution of $\sim 2.8^{\circ} \times 2.8^{\circ}$ with 31 vertical levels between the surface and $10 \mathrm{hPa}$.

GLOMAP-mode simulates aerosol component mass and number concentration (two-moment modal) in seven lognormal modes: hygroscopic nucleation, Aitken, accumulation and coarse modes plus a non-hygroscopic Aitken, accumulation and coarse modes. The aerosol components simulated are sulfate, sea salt, black carbon, particulate organic matter (POM) and dust. GLOMAP includes representations of nucleation, particle growth via coagulation, condensation and cloud processing, wet and dry deposition and in/below-cloud scavenging. Mann et al. (2012) demonstrated that the modal version of GLOMAP simulates very similar aerosol compared to the sectional version of the same model (Spracklen et al., 2005).

In this work we implemented fungal spore and bacteria emissions into GLOMAP. We used emissions of fungal spores from the empirically optimised scheme of Heald and Spracklen (2009), where emissions are driven by leaf area index (LAI) and atmospheric water vapour concentrations. We apply the fine- and coarse-mode emissions calculated by Heald and Spracklen (2009), assuming that the fine mode emissions are emitted with a diameter of $1.25 \mu \mathrm{m}$ and the coarse mode emissions are emitted at $6.25 \mu \mathrm{m}$. For bacteria emissions we followed Hoose et al. (2010b) which itself is based on Burrows et al. (2009b). Burrows et al. (2009b) used observations of bacteria number concentration synthesised from the literature (Burrows et al., 2009a) to estimate ecosystem-dependent fluxes. We applied ecosystem-dependent bacteria emission fluxes to match the upper emission estimate in Hoose et al. (2010b): oceans $226 \mathrm{~m}^{-2} \mathrm{~s}^{-1}$, crops $1578 \mathrm{~m}^{-2} \mathrm{~s}^{-1}$, forests $187 \mathrm{~m}^{-2} \mathrm{~s}^{-1}$, grasslands $1811 \mathrm{~m}^{-2} \mathrm{~s}^{-1}$, shrubs $619 \mathrm{~m}^{-2} \mathrm{~s}^{-1}$, tundra $579 \mathrm{~m}^{-2} \mathrm{~s}^{-1}$, and desert/land-ice $52 \mathrm{~m}^{-2} \mathrm{~s}^{-1}$. We used the MODIS International Global Biosphere Programme (IGBP) global land cover classification to determine the spatial distribution of different ecosystems. We mapped ecosystem types defined by Burrows et al. (2009a) onto MODIS IGBP land cover classifications, weighting the emission flux by the area fraction of each ecosystem as determined by MODIS. The global average annual mean land-surface bacteria emission flux is $410 \mathrm{~m}^{-2} \mathrm{~s}^{-1}$ in our implementation, which is similar to the $380 \mathrm{~m}^{-2} \mathrm{~s}^{-1}$ reported by Burrows 
et al. (2009a). Note the emission scheme for bacteria does not include a dependence on LAI. We used an emission diameter of $1 \mu \mathrm{m}$ for bacteria as used by previous studies (Hoose et al., 2010a). We assumed that both bacteria and fungal spores are composed of POM, are hydrophilic on emission (Heald and Spracklen, 2009) and are emitted into the hygroscopic modes. Other global model studies (e.g. Sesartic et al., 2013) have assumed that fungal spores are hydrophobic on emission, with this assumption extending the simulated lifetime of PBAPs.

$\mathrm{CCN}$ concentrations were calculated using the simulated aerosol size distribution and the approach of Petters and Kreidenweis (2007). We assign hygroscopicity parameters for sulfate (0.61, assuming ammonium sulfate), sea salt (1.28), black carbon (0.0), and POM (0.1). To calculate the potential contribution of PBAPs to ice nucleation, we quantified the contribution of different aerosol sources (dust, soot, bacteria and fungal spores) to immersion freezing rates: the dominant heterogeneous ice nucleation pathway in mixed-phase clouds (Hoose et al., 2010a). We calculate immersion freezing rates using the parameterisation of Hoose et al. (2010a, b) which is based on classical nucleation theory and laboratory experiments. As in Hoose et al. (2010a, b) we assumed that only $0.1 \%$ of fungi and bacteria and $1 \%$ of soot have the potential to be IN active. No upper limit is applied for dust (100\% of particles can act as IN). The potential of PBAPs to nucleate ice is uncertain (Murray et al., 2012), so we carried out a sensitivity study where we assumed that all PBAPs can be IN active with no upper limits for IN formation from PBAPs. This simulation matches the PBAP-max simulation in Hoose et al. (2010a, b). We report immersion freezing rates in two ways: all sky and weighted by ice-cloud fraction. We apply monthly mean ice cloud fraction from the International Satellite Cloud Climatology Project (ISCCP) D-2 data (Rossow and Schiffer, 1999) for the year 2000.

\subsection{PBAP observations}

We compared simulated PBAP number concentrations against observations synthesised from the literature. Observations of the number concentration of PBAPs in the atmosphere are limited, long-term observations are rare and there are specific measurement issues. For example, many studies report the number of culturable fungi or bacteria, despite the fact that this method only accounts for a fraction of the total number (Burrows et al., 2009a). For bacteria, the fraction of total bacteria which are cultural can be as low as $1 \%$ (Burrows et al., 2009a). Furthermore, most observational techniques rely on manual counting, a method that is subject to significant operator bias.

We used two previous studies that had synthesised observations of the number concentrations of fungal spores (Sesartic and Dallafior, 2011) and bacteria (Burrows et al., 2009a) in surface air. Sesartic and Dallafior (2011) synthesised observations of fungal spores from both culturable and culture- independent techniques. We report the mean, maximum and minimum of the observations. Burrows et al. (2009a) synthesised observations of number concentration of bacteria, applying scaling factors to convert culturable to total bacteria concentrations. They give a best estimate as well as upper and lower bounds through which they attempt to account for uncertainty in both culturable bacteria number concentration as well as the ratio of total to culturable bacteria. Both studies report number concentrations as a function of broad ecosystem types (forest, shrub, grassland, crop, tundra). We used the IGBP land cover classification from MODIS to sample the model in a similar manner.

To further evaluate fungal spore number concentrations, we synthesised observations of long-term (those with at least a full annual cycle) fungal spore number concentrations from the literature (Ho et al., 2005; Sousa et al., 2009; GrinnGofron et al., 2011; Herrero et al., 2006; Lim et al., 1998; Henriquez et al., 2001; Hasnain et al, 2012). Observations are typically made using 7-day spore traps and microscopic identification and counting techniques; these methods are inherently uncertain and subject to operator error. Observations are available in both hemispheres and are primarily located in urban regions.

\section{Results}

We compare our calculated global annual mean mass burden of fungal spores and bacteria to that previously reported using the same PBAP emission schemes. The simulated global annual mean burden of fungal spores calculated here $(0.15 \mathrm{Tg})$ matches that previously reported using GEOS-Chem (0.18 Tg) (Heald and Spracklen, 2009) and CAM-Oslo (0.094 Tg) (Hoose et al., 2010b). The simulated global annual mean burden of bacteria calculated here $(0.011 \mathrm{Tg})$ is also similar to previously reported by Burrows et al. (2009b) (0.0087 Tg) and simulated using CAM-Oslo (0.0043 Tg) (Hoose et al., 2010b).

Figure 1 shows simulated surface annual mean number concentrations of fungal spores and bacteria. GLOMAPmode simulates similar continental surface mean number concentrations for both fungal spores $\left(2.4 \times 10^{4} \mathrm{~m}^{-3}\right)$ and bacteria $\left(1.9 \times 10^{4} \mathrm{~m}^{-3}\right)$, but with different spatial patterns. Simulated concentrations of fungal spores are typically $2 \times$ $10^{4} \mathrm{~m}^{-3}$ over midlatitude continental regions and exceed $1 \times 10^{5} \mathrm{~m}^{-3}$ over tropical forests matching the regions of greatest fungal spore emission (Heald and Spracklen, 2009). Simulated surface concentrations of bacteria are typically $2 \times 10^{4} \mathrm{~m}^{-3}$ over most continental regions, but are greater over grassland regions of central Asia and North America where concentrations of $5 \times 10^{4} \mathrm{~m}^{-3}$ are more typical. Simulated concentrations of bacteria are lower over tropical forest regions than over other continental regions due to low emission flux assumed for these ecosystems combined with rapid wet deposition. Over oceans, annual mean concentrations of 


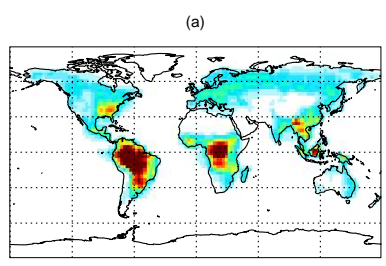

$\longdiv { 2 5 0 0 0 \quad 5 0 0 0 0 7 5 0 0 0 1 0 0 0 0 0 \mathrm { m } ^ { - 3 } }$

(c)

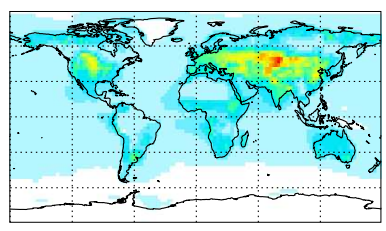

$0 \longdiv { 2 5 0 0 0 } 5 0 0 0 0 \quad 7 5 0 0 0 1 0 0 0 0 0 \mathrm { m } ^ { - 3 }$

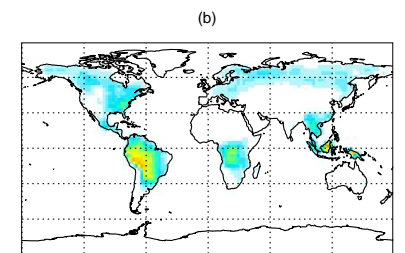

$\begin{array}{lllll}0.00 & 0.25 & 0.50 & 0.75 & 1.00\end{array}$

(d)

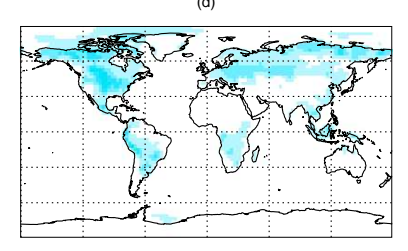

$\begin{array}{lllll}0.00 & 0.25 & 0.50 & 0.75 & 1.00\end{array}$
Figure 1. Simulated surface annual mean (a) fungal spore number concentrations, (b) fractional contribution of fungal spores to supermicron surface number, (c) bacteria number concentrations and (d) fractional contribution of bacteria to supermicron number concentrations.

bacteria $\left(7.8 \times 10^{3} \mathrm{~m}^{-3}\right)$ are substantially greater than fungal spores $\left(1.9 \times 10^{3} \mathrm{~m}^{-3}\right)$, since we apply an ocean flux of bacteria but no such flux for fungal spores. The global mean ratio of continental surface number concentration to marine surface number concentration is 2.5 for bacteria and 12 for fungal spores. The magnitude and spatial distribution of our simulated bacteria number concentrations is similar to that simulated by Burrows et al. (2009b).

Figure 2 compares simulated number concentrations of fungal spores and bacteria in surface air against observations (Sesartic and Dallafior, 2011; Burrows et al., 2009a). Both studies report observed number concentration as a function of ecosystem type. We used the MODIS IGBP land cover classification to sample the model in a similar manner to that of the observational studies. Observed fungal spore concentrations are typically $\sim 1 \times 10^{4} \mathrm{~m}^{-3}$. Fungal spore number concentrations are simulated to within a factor of 3 over shrub, grassland and crop ecosystems. Over forests, the model overpredicts observed concentrations of fungal spores. Limiting the observational data set to culture independent techniques (Sesartic and Dallafior, 2011) increases observed concentrations by only $40 \%$ on average and is not sufficient to explain the model bias. It is possible that the linear dependence of emission flux on LAI applied by Heald and Spracklen (2009) is too strong, or that the particle size we apply over these ecosystems is too small. Additional observations over tropical ecosystems are required to explore this further.

Bacteria number concentrations simulated by the model reasonably match (within a factor of 2) observed number concentrations over ocean, desert/ice and tundra environments, but are underpredicted by a factor of $2-4$ over forests,
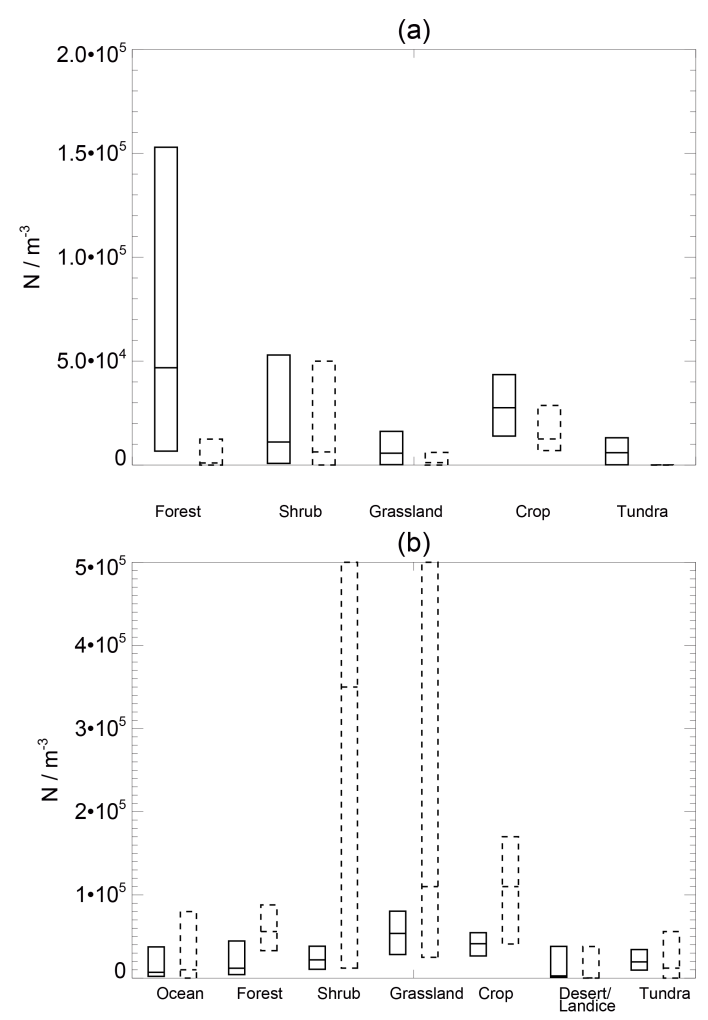

Figure 2. Comparison of simulated (solid) and observed (dashed) surface (a) fungal spore and (b) bacteria number concentrations across different ecosystems. Boxes show minimum, mean and maximum concentrations. Observed concentrations are a synthesis of fungal spore (Sesartic and Dallafior, 2011) and total bacteria (Burrows et al., 2009a) number concentrartions in near-surface air. The observed maximum for shrub and grasslands is $8.4 \times 10^{4} \mathrm{~m}^{-3}$ and extends off the scale. Simulated concentrations are the mean, maximum and minimum annual mean surface concentrations for that ecosystem type.

grasslands and crops (Fig. 2b). Given that we are employing bacteria emissions from Burrows et al. (2009b) which are based on these observations, good agreement for bacteria is expected. Poor understanding of the seasonal cycle in emissions (Burrows et al., 2009a; Hoose et al., 2010b), combined with the limited set of observations, precludes a more quantitative comparison.

To further evaluate simulated fungal spore number concentrations we compared against long-term observation of fungal spore number (Fig. 3). The model reasonably captures (within a factor of 2) observed annual mean number concentrations at some sites (Taiwan, Portugal, Spain and Chile), but overpredicts at other locations (Poland and Singapore). As a mean across all sites, simulated annual mean number concentrations are biased high (normalised mean bias (NMB) $=52 \%$ ), driven by the high model bias for Singapore. Despite this bias, the model typically captures the observed seasonal cycle at Northern Hemisphere $(\mathrm{NH})$ midlatitude sites 

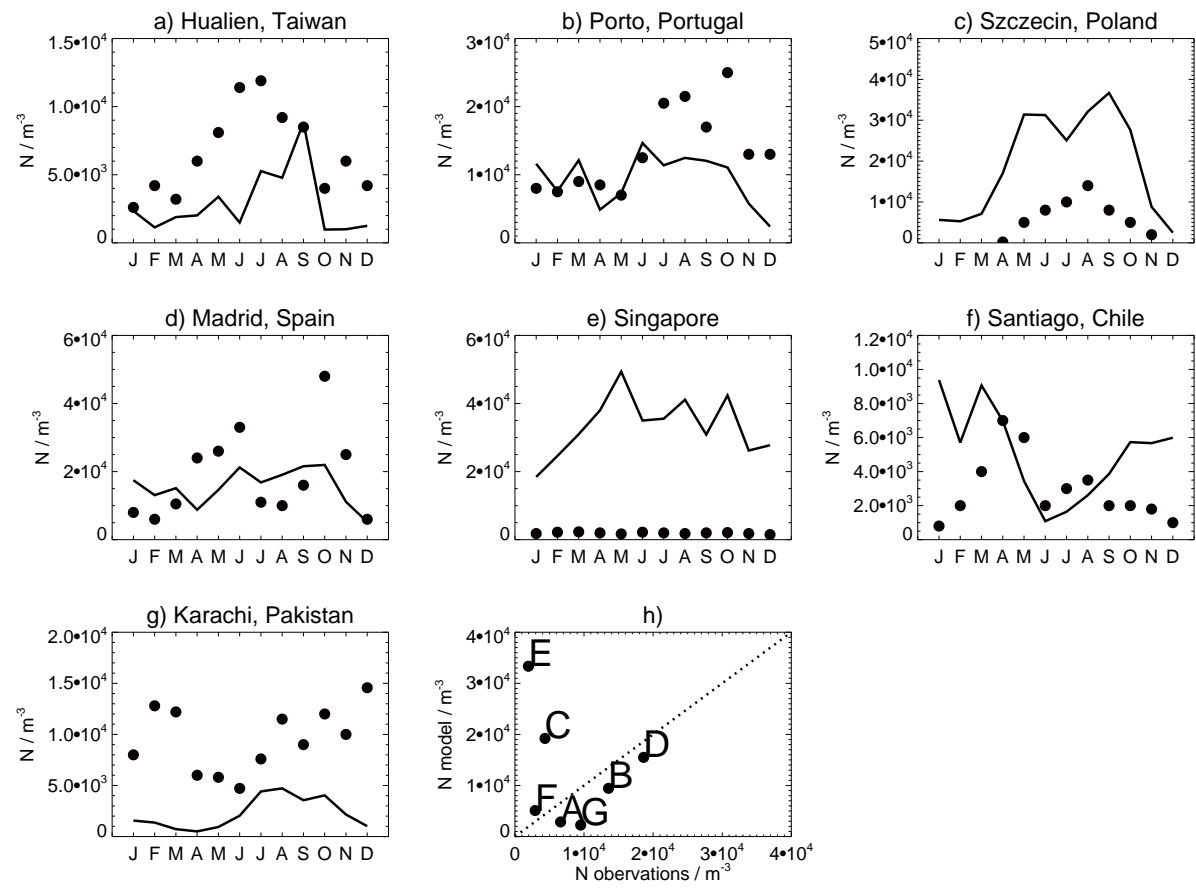

Figure 3. Evaluation of simulated fungal spore number concentrations. (a-g) Comparison of observed (circles) and simulated (black lines) monthly mean concentrations. (h) Comparison of simulated and observed annual mean concentrations. Observations are from Ho et al. (2005), Sousa et al. (2009), Grinn-Gofron et al. (2011), Herrero et al. (2006), Lim et al. (1998), Henriquez et al. (2001), and Hasnain et al. (2012).

with greater number concentrations during the summer as observed (Tong and Lighthart, 2000; Yttri et al., 2011; Bowers et al., 2013).

We calculated the simulated contribution of fungal spores and bacteria to total supermicron number concentrations. Previous model evaluations have demonstrated that GLOMAP reasonably simulates the mass and number concentrations of dust (Manktelow et al., 2010) and sea spray (Mann et al., 2012), giving us confidence in the distribution of other supermicron particle sources. Fungal spores are simulated to contribute $8 \%$ of annual mean continental surface supermicron number concentrations. The contribution is typically $\sim 25 \%$ over much of the continental $\mathrm{NH}$ midlatitudes matching observed contributions in these regions (Matthias-Maser and Jaenicke, 1995; Matthias-Maser et al., 2000). Over tropical forest regions we simulate that fungal spores contribute up to $50 \%$ of supermicron number concentrations (Fig. 1b), similar to the large observed contribution (Pöschl et al., 2010; Huffman et al., 2012). Bacteria have a smaller simulated contribution to surface supermicron number concentrations, contributing $5 \%$ to continental mean supermicron number concentrations, with a maximum contribution of $25 \%$ over parts of North America, boreal Asia and southern Africa (Fig. 1d). Over the oceans, where sea spray dominates supermicron aerosol number and the PBAP emission flux is smaller, the contribution of PBAPs is small (sur- face ocean mean of $0.4 \%$ for fungal spores and $1 \%$ for bacteria).

Figure 4 shows simulated zonal annual mean number concentrations of fungal spores and bacteria, exhibiting similar patterns to previous studies (Hoose et al., 2010b; Sesartic et al., 2013). Hoose et al. (2010a, b) apply a similar mass emission of fungal spores compared to our study but assume a larger emission diameter (they emit all spores at $5 \mu \mathrm{m}$ ), explaining the greater number concentrations we simulate both at the surface and aloft. We also simulate greater number concentration of fungal spores compared to Sesartic et al. (2013), at least partly due to the greater emission flux we apply in our study. Our simulated zonal annual mean number concentrations of fungal spores and bacteria are greatest in the lower troposphere (number concentrations up to $1 \times 10^{4} \mathrm{~m}^{-3}$ ) decreasing to about $100 \mathrm{~m}^{-3}$ at $400 \mathrm{hPa}$. Number concentrations of soot and dust are substantially larger, with annual zonal mean soot and dust number concentrations as large as 1000 and $1 \mathrm{~cm}^{-3}$ respectively in the NH lower troposphere.

The low number concentrations of PBAPs in comparison to other aerosol types means that both fungal spores and bacteria have little impact on global CCN concentrations. In our simulations, bacteria increase global mean surface $\mathrm{CCN}$ concentrations $(0.2 \%$ supersaturation $)$ by $0.01 \%$. Including fungal spores in the model reduces global mean surface CCN concentrations very slightly (by $0.001 \%$ ) through a marginal suppression of nucleation. Regionally, both bacteria 

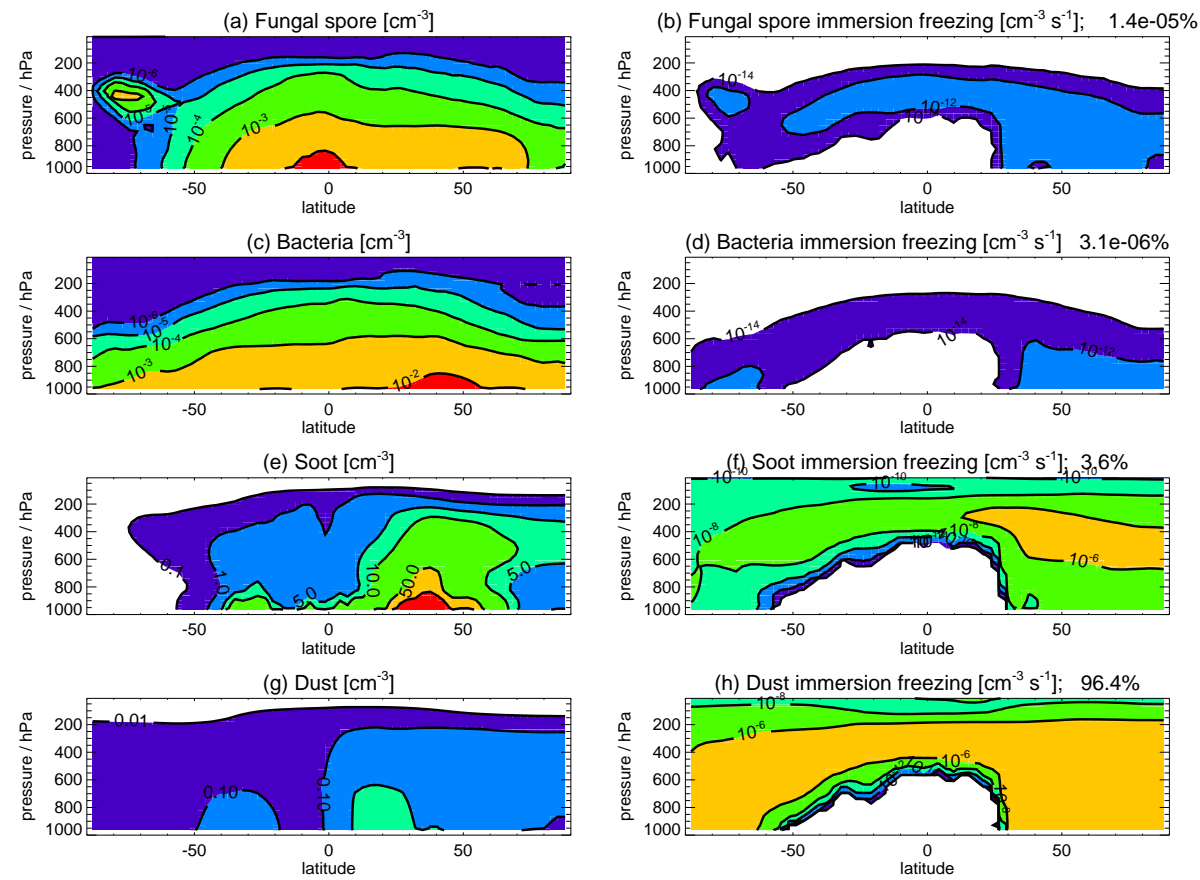

Figure 4. Zonal annual mean number concentrations for (a) fungal spores, (c) bacteria, (e) soot, (g) dust and all-sky immersion freezing rates for (b) fungal spores, (d) bacteria, (f) soot and (h) dust. Note (e) and (g) have a different colour scale to (a) and (c). Numbers above panel show percentage contribution to annual mean all-sky freezing rate. Weighting by ice-cloud fraction does not greatly change fractional contribution (see text).

and fungal spores alter $\mathrm{CCN}$ concentrations by less than $1 \%$ even over tropical forest regions.

Figure 4 shows zonal annual mean all-sky immersion freezing rates for fungal spores, bacteria, soot and dust. We find that global immersion freezing rates are dominated by dust $(96.4 \%)$ and soot $(3.6 \%)$ with PBAPs contributing only $1.4 \times 10^{-5} \%$. When we calculate immersion freezing rates weighted by ice-cloud fraction, global annual mean rates are still dominated by dust $(97.2 \%)$ with smaller contributions from soot $(2.8 \%)$, fungal spores $\left(8.1 \times 10^{-6} \%\right)$ and bacteria $\left(1.3 \times 10^{-6} \%\right)$. Hoose et al. $(2010 \mathrm{a}, \mathrm{b})$ also calculated a minimal contribution from PBAPs $\left(1.2 \times 10^{-5} \%\right)$ with large contributions from dust $(87.6 \%)$ and soot $(12.4 \%)$. The lower contribution from soot in our study is due to the lower absolute number concentrations of soot that we simulate. We simulate a larger all-sky contribution from PBAPs $\left(3 \times 10^{-3} \%\right)$ under the upper limit for IN formation from PBAPs, but global rates are still dominated by dust and soot.

Our simulated spatial pattern of immersion freezing rates is similar to that from previous studies (e.g. Hoose et al., $2010 \mathrm{~b}$ ). Bacteria and fungal spore immersion freezing rates are greatest in the lower troposphere at high latitudes and 400 to $600 \mathrm{hPa}$ in the tropics. Immersion freezing rates of soot and dust are maximum at higher altitudes, being greatest at 400 to $600 \mathrm{hPa}$ at high latitudes and 400 to $200 \mathrm{hPa}$ in the tropics. Above $400 \mathrm{hPa}$, immersion freezing rates of soot and dust are as large as $1 \times 10^{-6} \mathrm{~cm}^{-3} \mathrm{~s}^{-1}$, several orders of mag- nitude greater than immersion freezing rates of either fungal spore or bacteria $\left(1 \times 10^{-14} \mathrm{~cm}^{-3} \mathrm{~s}^{-1}\right)$. However, at lower altitudes simulated immersion freezing rates of PBAPs, dust and soot are more comparable. Between 400 and $600 \mathrm{hPa}$, simulated freezing rates of fungal spores and bacteria are as great as $1 \times 10^{-12} \mathrm{~cm}^{-3} \mathrm{~s}^{-1}$, greater than the freezing rates of soot or dust at these altitudes. Dust and soot are known to be important $\mathrm{IN}$ at temperatures below about $-15^{\circ} \mathrm{C}$, but their ability to nucleate ice at warmer temperatures is unclear (Murray et al., 2012).

Figure 5 shows the contribution of PBAPs (bacteria and fungal spores) to total all-sky zonal annual mean immersion freezing rates. Above $400 \mathrm{hPa}$, PBAPs contribute less than $0.001 \%$ to zonal annual mean immersion freezing rates. At warmer temperatures, PBAPs can make an important contribution to zonal annual mean freezing rates with contribution to total freezing rates reaching $100 \%$.

To examine this behaviour in more detail, Fig. 6 shows the contribution of PBAPs to immersion freezing rates at 260 and $263 \mathrm{~K}$ in July 2000 . Freezing rates are weighted by icecloud fraction. At $263 \mathrm{~K}$, PBAP contributes $\sim 20-100 \%$ of total immersion freezing rates over most continental regions, with lower contribution over most oceanic regions. At $260 \mathrm{~K}$, PBAP contributes typically $1-10 \%$ to total immersion freezing rates. We note that very small immersion freezing rates at warmer temperatures may have limited atmospheric impacts. 


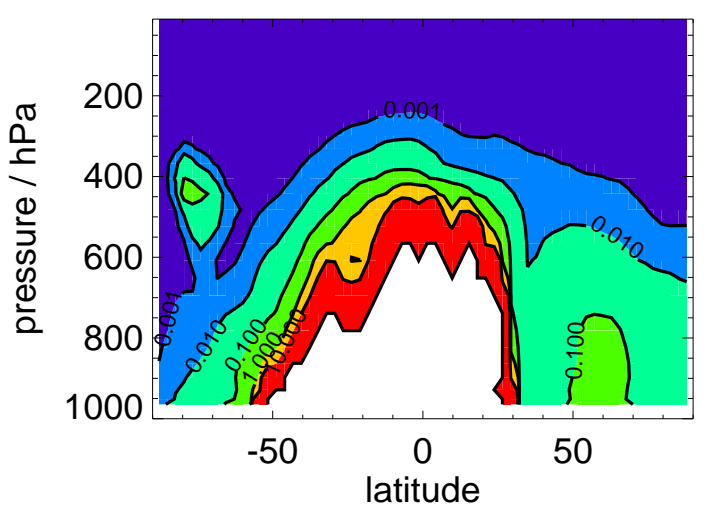

Figure 5. Percentage contribution of PBAPs (bacteria and fungal spores) to zonal annual mean all-sky immersion freezing rates. Values are for the upper limit contribution of PBAPs to immersion freezing (see text). White colour shows where total immersion freezing rate is less than $1 \times 10^{-14} \mathrm{~cm}^{-3} \mathrm{~s}^{-1}$.

\section{Discussion and conclusions}

We have explored the contribution of fungal spores and bacteria to global aerosol number concentrations. We included existing emission schemes for fungal spores and bacteria in a global aerosol microphysics model. Simulated surface number concentrations of fungal spores and bacteria were typically $2 \times 10^{4} \mathrm{~m}^{-3}$ over many continental regions. Simulated number concentrations reasonably matched (typically within a factor of 2) available observations, although the model overpredicts fungal spore concentrations over forest ecosystems and underpredicts bacteria number concentrations over grass, shrub and crop ecosystems. A more detailed evaluation of the model is not possible because observations of fungal spore and bacteria number are limited, are subject to methodological issues and rely on counting techniques with inherent operator error. Long-term observations (longer than a few weeks) of PBAP number are particularly scarce. New methods employing laser-induced fluorescence to identify and count biological particles (e.g. Gabey et al., 2010, 2011; Huffman et al., 2010) may offer new opportunities to evaluate model predictions. We note that existing PBAP emission schemes have not been designed to adequately represent seasonal and interannual variability.

We found that fungal spores and bacteria contributed 8 and $5 \%$ respectively to global continental mean supermicron number concentrations. Regionally, the contribution was greater with fungal spores contributing $25 \%$ of supermicron number concentration over many continental midlatitude regions and up to $50 \%$ over tropical forests. The low number concentrations of fungal spores and bacteria compared to other aerosol types result in a limited contribution $(<1 \%)$ of PBAPs to regional CCN concentrations. It is important to note that PBAPs may be able to act as giant
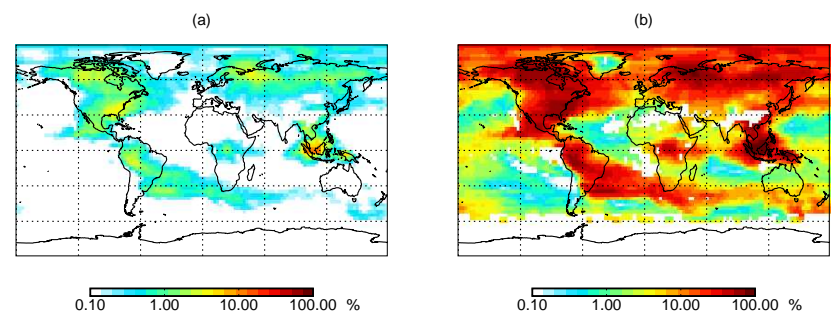

Figure 6. Percentage of immersion freezing simulated to be due to PBAPs (bacteria and fungal spores) in July 2000 at (a) $260 \mathrm{~K}$ and (b) $263 \mathrm{~K}$. Values are for the upper limit contribution of PBAPs to immersion freezing and are weighted by ice cloud fraction (see text).

(>2 $\mu \mathrm{m}$ ) CCN (Möhler et al., 2007), something that we did not study here.

We used an existing parameterisation of immersion freezing rates (Hoose et al., 2010a, b) in combination with our simulated aerosol number to quantify the contribution of PBAPs to ice nucleation. We found that fungal spores and bacteria contribute less than $3 \times 10^{-3} \%$ to global all-sky immersion freezing rates, matching recent global model studies that find PBAPs to be unimportant as a source of IN at the global scale (Hoose et al., 2010a, b). We find a similarly small contribution of PBAPs to global immersion freezing rates when we weighted freezing rates by ice cloud fraction. Although PBAP has little impact on global immersion freezing rates, we found PBAPs may be important at altitudes between 400 and $600 \mathrm{hPa}$, where warm temperatures $\left(>-15^{\circ} \mathrm{C}\right)$ inhibit the formation of ice from soot and dust. At these altitudes, PBAPs dominate immersion freezing rates in our simulations, matching case study observations that recorded a large contribution of PBAP to IN formation (Christner et al., 2008; Pratt et al., 2009; Prenni et al., 2009).

Whilst we acknowledge that the IN activity of fungal spores and bacteria is uncertain (Murray et al., 2012; Hoose and Möhler, 2012), our study suggests that there are regions of the atmosphere where biological particles contribute substantially to small ice nucleation rates, motivating additional research on the role of PBAPs as IN. Furthermore, recent studies have suggested that PBAP emissions are related to rainfall and relative humidity (Huffman et al., 2013; Schumacher et al., 2013; Prenni et al., 2013) creating daily variability in emissions not accounted for here and potentially leading to tighter coupling between PBAP emissions and climate.

Acknowledgements. This work was supported by the Natural Environment Research Council (NE/G015015/1) and by the U.S. National Science Foundation (AGS-1238109).

Edited by: A. Nenes 


\section{References}

Bauer, H., Giebl, H., Hitzenberger, R., Kasper-Giebl, A., Reischl, G., Zibuschka, F., and Puxbaum, H.: Airborne bacteria as cloud condensation nuclei, J. Geophys. Res., 108, 4658, doi:10.1029/2003JD003545, 2003.

Bowers, R. M., Clements, N., Emerson, J. B., Wiedinmyer, C., Hannigan, M. P., and Fierer, N.: Seasonal variability in bacterial and fungal diversity of the near surface atmosphere, Environ. Sc. Technol., 47, 12097-12106, 2013.

Burrows, S. M., Elbert, W., Lawrence, M. G., and Pöschl, U.: Bacteria in the global atmosphere - Part 1: Review and synthesis of literature data for different ecosystems, Atmos. Chem. Phys., 9, 9263-9280, doi:10.5194/acp-9-9263-2009, 2009a.

Burrows, S. M., Butler, T., Jöckel, P., Tost, H., Kerkweg, A., Pöschl, U., and Lawrence, M. G.: Bacteria in the global atmosphere - Part 2: Modeling of emissions and transport between different ecosystems, Atmos. Chem. Phys., 9, 9281-9297, doi:10.5194/acp-9-9281-2009, 2009b.

Chipperfield, M. P.: New version of the TOMCAT/SLIMCAT offline chemical transport model,Intercomparison of stratospheric tracer experiments, Q. J. R. Meteorolo. Soc., 132, 1179-1203, 2006.

Christner, B. C., Morris, C. E., Foreman, C. M., Cai, R. M., and Sands, D. C.: Ubiquity of biological ice nucleators in snowfall, Science, 319, 1214-1214, doi:10.1126/science.1149757, 2008.

DeLeon-Rodriguez, N., Lathem, T. L., Rodriguez-R, L. M., Barazesh, J. M., Anderson, B. E., Beyersdorf, A. J., Ziemba, L. D., Bergin, M., Nenes, A., and Konstantinidis, K. T.: Microbiome of the upper troposphere: Species composition and prevalence, effects of tropical storms, and atmospheric implications, P. Natl. Acad. Sci. USA, 110, 2575-2580 doi:10.1073/pnas.1212089110, 2013

Després, V. R., Huffman, J. A., Burrows, S. M., Hoose, C., Safatov, A. S., Buryak, G., Fröhlich-Nowoisky, J., Elbert, W., Andreae, M. O., Pöschl, U., and Jaenicke, R.: Primary biological aerosol particles in the atmosphere: a review, Tellus, 64B, 15598, doi:10.3402/tellusb.v64i0.15598, 2012.

Elbert, W., Taylor, P. E., Andreae, M. O., and Pöschl, U.: Contribution of fungi to primary biogenic aerosols in the atmosphere: wet and dry discharged spores, carbohydrates, and inorganic ions, Atmos. Chem. Phys., 7, 4569-4588, doi:10.5194/acp-7-4569-2007, 2007

Gabey, A. M., Gallagher, M. W., Whitehead, J., Dorsey, J. R., Kaye, P. H., and Stanley, W. R.: Measurements and comparison of primary biological aerosol above and below a tropical forest canopy using a dual channel fluorescence spectrometer, Atmos. Chem. Phys., 10, 4453-4466, doi:10.5194/acp-10-4453-2010, 2010.

Gabey, A. M., Stanley, W. R., Gallagher, M. W., and Kaye, P. H.: The fluorescence properties of aerosol larger than $0.8 \mu \mathrm{m}$ in urban and tropical rainforest locations, Atmos. Chem. Phys., 11, 5491-5504, doi:10.5194/acp-11-5491-2011, 2011.

Grinn-Gofron, A., Strzelczak, A., and Wolski, T.: The relationship between air pollutants, meteorological parameters and concentration of airborne fungal spores, Environ. Pollut., 159, 602-608, 2011

Hasnain, S. M., Akhter, T., and Waqarm, M. A.: Airborne and allergenic fungal spores of the Karachi environment and their correlation with meteorological factors, J. Environ. Monit., 14 , 1006$1013,2012$.
Heald, C. L. and Spracklen, D. V.: Atmospheric budget of primary biological aerosol particles from fungal spores, Geophys. Res. Lett., 36, L09806, doi:10.1029/2009GL037493, 2009.

Henríquez, V. I., Villegas, G. R. and Nolla, J. M. R.: Airborne fungi monitoring in Santiago, Chile, Aerobiologia, 17, 137-142, 2001.

Herrero, A. D., Ruiz, S. S., Bustillo, M. G., and Morales, P. C.: Study of airborne fungal spores in Madrid, Spain, Aerobiologia, 22, 135-142, 2006.

Ho, H. M., Rao, C. Y., Hsu, H. H., Chiu, Y. H., Liu, C. M., and Chao, H. J.: Characteristics and determinants of ambient fungal spores in Hualien, Taiwan, Atmos. Environ., 39, 5839-50, doi:10.1016/j.atmosenv.2005.06.034, 2005.

Hoose, C. and Möhler, O.: Heterogeneous ice nucleation on atmospheric aerosols: a review of results from laboratory experiments, Atmos. Chem. Phys., 12, 9817-9854, doi:10.5194/acp-12-98172012, 2012.

Hoose, C., Kristjánsson, J. E., and Burrows, S. M.: How important is biological ice nucleation in clouds on a global scale?, Environ. Res. Lett., 5, 024009, doi:10.1088/1748-9326/5/2/024009, 2010a.

Hoose, C., Kristjánsson, J. E., Chen, J.-P., and Harza, A. A.: classical-theory-based parameterization of heterogeneous ice nucleation by mineral dust, soot, and biological particles in a global climate model, J. Atmos. Sci., 67, 2483-2503, 2010b.

Huffman, J. A., Treutlein, B., and Pöschl, U.: Fluorescent biological aerosol particle concentrations and size distributions measured with an Ultraviolet Aerodynamic Particle Sizer (UVAPS) in Central Europe, Atmos. Chem. Phys., 10, 3215-3233, doi:10.5194/acp-10-3215-2010, 2010.

Huffman, J. A., Sinha, B., Garland, R. M., Snee-Pollmann, A., Gunthe, S. S., Artaxo, P., Martin, S. T., Andreae, M. O., and Pöschl, U.: Size distributions and temporal variations of biological aerosol particles in the Amazon rainforest characterized by microscopy and real-time UV-APS fluorescence techniques during AMAZE-08, Atmos. Chem. Phys., 12, 11997-12019, doi:10.5194/acp-12-11997-2012, 2012.

Huffman, J. A., Prenni, A. J., DeMott, P. J., Pöhlker, C., Mason, R. H., Robinson, N. H., Fröhlich-Nowoisky, J., Tobo, Y., Després, V. R., Garcia, E., Gochis, D. J., Harris, E., Müller-Germann, I., Ruzene, C., Schmer, B., Sinha, B., Day, D. A., Andreae, M. O., Jimenez, J. L., Gallagher, M., Kreidenweis, S. M., Bertram, A. K., and Pöschl, U.: High concentrations of biological aerosol particles and ice nuclei during and after rain, Atmos. Chem. Phys., 13, 6151-6164, doi:10.5194/acp-13-6151-2013, 2013.

Jaenicke, R.: Abundance of cellular material and proteins in the atmosphere, Science, 308, 73, 2005.

Jacobson, M. Z. and Streets, D. G.: Influence of future anthropogenic emissions on climate, natural emissions and air quality, J. Geophys. Res., 114, D08118, doi:10.1029/2008JD011476, 2009.

Lim, S. H., Chew, F. T., Dali, S. D. B. M., Tan, T. W., Lee, B. W., and Tan, T. K.: Outdoor airborne fungal spores in Singapore, Grana, 37 (4), 246-252, 1998.

Manktelow, P. T., Carslaw, K. S., Mann, G. W., and Spracklen, D. V.: The impact of dust on sulfate aerosol, $\mathrm{CN}$ and $\mathrm{CCN}$ during an East Asian dust storm, Atmos. Chem. Phys., 10, 365-382, doi:10.5194/acp-10-365-2010, 2010.

Mann, G. W., Carslaw, K. S., Spracklen, D. V., Ridley, D. A., Manktelow, P. T., Chipperfield, M. P., Pickering, S. J., and 
Johnson, C. E.: Description and evaluation of GLOMAP-mode: a modal global aerosol microphysics model for the UKCA composition-climate model, Geosci. Model Dev., 3, 519-551, doi:10.5194/gmd-3-519-2010, 2010.

Mann, G. W., Carslaw, K. S., Ridley, D. A., Spracklen, D. V., Pringle, K. J., Merikanto, J., Korhonen, H., Schwarz, J. P., Lee, L. A., Manktelow, P. T., Woodhouse, M. T., Schmidt, A., Breider, T. J., Emmerson, K. M., Reddington, C. L., Chipperfield, M. P., and Pickering, S. J.: Intercomparison of modal and sectional aerosol microphysics representations within the same 3-D global chemical transport model, Atmos. Chem. Phys., 12, 4449-4476, doi:10.5194/acp-12-4449-2012, 2012.

Matthias-Maser, S. and Jaenicke, R.: The size distribution of primary biological aerosol particles with radii $>0.2 \mu \mathrm{m}$ in an urban rural influenced region, Atmos. Res., 39, 279-286, 1995.

Matthias-Maser, S., Obolkin, V., Khodzer, T., and Jaenicke, R.: Seasonal variation of primary biological aerosol particles in the remote continental region of Lake Baikal/Siberia, Atmos. Environ., 34, 3805-3811, 2000.

Möhler, O., DeMott, P. J., Vali, G., and Levin, Z.: Microbiology and atmospheric processes: the role of biological particles in cloud physics, Biogeosciences, 4, 1059-1071, doi:10.5194/bg-4-10592007, 2007.

Murray, B. J., O'Sullivan, D., Atkinson, J. D., and Webb, M. E.: Ice nucleation by particles immersed in supercooled cloud droplets, Chem. Soc. Rev., 41, 6519-6554, 2012.

Petters, M. D. and Kreidenweis, S. M.: A single parameter representation of hygroscopic growth and cloud condensation nucleus activity, Atmos. Chem. Phys., 7, 1961-1971, doi:10.5194/acp-71961-2007, 2007.

Phillips, V. T. J., Andronache, C., Christner, B., Morris, C. E., Sands, D. C., Bansemer, A., Lauer, A., McNaughton, C., and Seman, C.: Potential impacts from biological aerosols on ensembles of continental clouds simulated numerically, Biogeosciences, 6 , 987-1014, doi:10.5194/bg-6-987-2009, 2009.

Pöschl, U., Martin, S. T., Sinha, B., Chen, Q., Gunthe, S. S., Huffman, J. A., Borrmann, S., Farmer, D. K., Garland, R. M., Helas, G., Jimenez, J. L., King, S. M., Manzi, A., Mikhailov, E., Pauliquevis, T., Petters, M. D., Prenni, A. J., Roldin, P., Rose, D., Schneider, J., Su, H., Zorn, S. R., Artaxo, P., Andreae, M. O.: Rainforest aerosols as biogenic nuclei of cloud and precipitation in the Amazon, Science, 329, 1513, doi:10.1126/science.1191056, 2010.

Pratt, K. A., DeMott, P. J., French, J. R., Wang, Z., Westphal, D. L., Heymsfield, A. J., Twohy, C. H., Prenni, A. J., and Prather, K. A.: In situ detection of biological particles in cloud ice-crystals, Nat. Geosci., 2, 398-401, 2009.
Prenni, A. J., Petters, M. D., Kreidenweis, S. M., Heald, C. L., Martin, S. T., Artaxo, P., Garland, R. M., Wollny, A. G., and Pöschl, U.: Relative roles of biogenic emissions and Saharan dust as ice nuclei in the Amazon basin, Nat. Geosci., 2, 402-5, 2009.

Prenni, A. J., Tobo, Y., Garcia, E., DeMott, P. J., Huffman, J. A., McCluskey, C. S., Kreidenweis, S. M., Prenni, J. E., Pöhlker, C., and Pöschl, U.: The impact of rain on ice nuclei populations at a forested site in Colorado, Geophys. Res. Lett., 40, 227-231, doi:10.1029/2012GL053953, 2013.

Rossow, W. B. and Schiffer, R. A.: Advances in Understanding Clouds from ISCCP, B. Am. Meteorol. Soc., 80, 2261-2287, 1999.

Schumacher, C. J., Pöhlker, C., Aalto, P., Hiltunen, V., Petäjä, T., Kulmala, M., Pöschl, U., and Huffman, J. A.: Seasonal cycles of fluorescent biological aerosol particles in boreal and semiarid forests of Finland and Colorado, Atmos. Chem. Phys., 13, 11987-12001, doi:10.5194/acp-13-11987-2013, 2013.

Sesartic, A. and Dallafior, T. N.: Global fungal spore emissions, review and synthesis of literature data, Biogeosciences, 8, 11811192, doi:10.5194/bg-8-1181-2011, 2011.

Sesartic, A., Lohmann, U., and Storelvmo, T.: Modelling the impact of fungal spore ice nuclei on clouds and precipitation, Environ. Res. Lett., 8, 014029, doi:10.1088/1748-9326/8/1/014029, 2013.

Sousa, S. I. V., Martins, F. G., Pereira, M. C., Alvim-Ferraz, M. C. M., Ribeiro, H., Oliveira, M., Abreu, I.: Influence of atmospheric ozone, PM10 and meteorological factors on the concentration of airborne pollen and fungal spore, Atmos. Environ., 43, 22282228, doi:10.1016/j.atmosenv.2008.06.052, 2009.

Spracklen, D. V., Pringle, K. J., Carslaw, K. S., Chipperfield, M. P., and Mann, G. W.: A global off-line model of sizeresolved aerosol microphysics: I. Model development and prediction of aerosol properties, Atmos. Chem. Phys., 5, 2227 2252, doi:10.5194/acp-5-2227-2005, 2005.

Tong, Y. Y. and Lighthart, B.: The annual bacterial particle concentration and size distribution in the ambient atmosphere in a rural area of the Willamette valley, Oregon, Aerosol. Sci. Technol., 32, 393-403, doi:10.1080/027868200303533, 2000.

Yttri, K. E., Simpson, D., Stenström, K., Puxbaum, H., and Svendby, T.: Source apportionment of the carbonaceous aerosol in Norway - quantitative estimates based on ${ }^{14} \mathrm{C}$, thermal-optical and organic tracer analysis, Atmos. Chem. Phys., 11, 9375-9394, doi:10.5194/acp-11-9375-2011, 2011. 